\title{
Natural Radioactivity in Building Materials, Indoor Radon Measurements and Assessment of the Associated Risk Indicators in Some Localities of the Centre-region, Cameroon
}

Joseph Emmanuel Ndjana Nkoulou II

Institute of Geological and Mining Research

André MANGA

Institute of Geological and Mining Research

Saïdou - ( $\sim$ saidous2002@yahoo.fr)

Institute of Geological and Mining Research https://orcid.org/0000-0001-7427-0239

Olga GERMAN

International Atomic Energy Agency

Carlos SAINZ-FERNANDEZ

University of Cantabria

Moïse Godfroy Kwato Njock

UNiversity of Douala

\section{Research Article}

Keywords: Natural radioactivity, building materials, RESRAD-BUILD, indoor radon, inhalation dose, risk indicators

Posted Date: January 20th, 2022

DOI: https://doi.org/10.21203/rs.3.rs-1196345/v1

License: (c) (i) This work is licensed under a Creative Commons Attribution 4.0 International License. Read Full License 


\title{
Natural radioactivity in building materials, indoor radon measurements and assessment of the associated risk indicators in some localities of the Centre-region, Cameroon
}

\author{
Joseph Emmanuel NDJANA NKOULOU II ${ }^{1,2}$, André MANGA², SAÏDOU ${ }^{2,3^{*}}$, Olga GERMAN ${ }^{4}$, \\ Carlos SAINZ-FERNANDEZ ${ }^{5}$ and Moïse Godfroy KWATO NJOCK ${ }^{1}$
}

${ }^{1}$ Centre for Atomic Molecular Physics and Quantum Optics, University of Douala, PO Box 8580, Douala, Cameroon

${ }^{2}$ Research Centre for Nuclear Science and Technology, Institute of Geological and Mining Research, PO Box 4110, Yaoundé, Cameroon.

${ }^{3}$ Faculty of Science, University of Yaoundé I, PO Box 812, Yaoundé, Cameroon

${ }^{4}$ Division of Radiation, Transport and Waste Safety, Department of Nuclear Safety and Security, International Atomic Energy Agency, P.O. Box 100, 1400, Wagramerstrasse, 1020 Vienna, Austria.

${ }^{5}$ Environmental Radioactivity Laboratory of the University of Cantabria (LaRUC), University of Cantabria, Santander, 39011 Cantabria, Spain

*Corresponding author’s e-mail: saidous2002@yahoo.fr

\section{Abstract}

The objective of the current study is to investigate natural radioactivity of some building materials, the resulting long-term external and internal effective dose equivalents (EEDE and IEDE) analysis followed by indoor radon measurements as well as the assessment of some radiological risk indicators associated with radon exposure. A total of 37 samples of building materials were analyzed with a sodium iodide detector $(\mathrm{NaI}(\mathrm{Tl}))$ and the computer code RESRAD-BUILD was used for the analysis of the EEDE and IEDE of the structural elements of the houses (walls and floor). For indoor radon measurements, 140 houses were selected and in each of them was placed 01 RADTRAK dosimeter. Inhalation dose, total dose and some radiological risk indicators were calculated. The specific activities of ${ }^{226} \mathrm{Ra},{ }^{232} \mathrm{Th}$ and ${ }^{40} \mathrm{~K}$ for the overall sampled building materials were found to vary between $10 \pm 2-52 \pm 7,10 \pm 1-95 \pm 10$ and $31 \pm 1-673 \pm 20 \mathrm{~Bq} \mathrm{~kg}^{-1}$ respectively. The dwelling types with bare brick walls, cement mortar plastered walls and concrete floors show EEDE and IEDE values well below the recommended limits. The corresponding dwelling types contributions to the measured average indoor radon concentration $\left(42 \pm 12 \mathrm{~Bq} \mathrm{~m}^{-3}\right)$ are $22 \%, 13 \%$ and $16 \%$ respectively. Inhalation dose resulting from the measured indoor radon concentrations varies from 0.35 to $3.24 \mathrm{mSv} \mathrm{y}^{-1}$ with a mean value of $0.96 \pm 0.55 \mathrm{mSv} \mathrm{y}^{-1}$, which represents about $65 \%$ of the total dose simulated $\left(1.49 \pm 0.88 \mathrm{mSv}^{-1}\right)$ by the RESRAD-BUILD code. The overall analysis of indoor radon-related radiological risk indicators shows low levels of risk relative to permissible limits.

KEYWORDS: Natural radioactivity, building materials, RESRAD-BUILD, indoor radon, inhalation dose, risk indicators. 


\section{INTRODUCTION}

\section{$1.1 \quad$ Background}

Human exposure to natural radiation sources is an ubiquitous natural phenomenon that has always existed (Valentin 1994; McLean et al. 2017). The United Nations Scientific Committee on the Effects of Atomic Radiation (UNSCEAR) has estimated that $80 \%(2.4 \mathrm{mSv}$ ) and $20 \%$ (about $0.7 \mathrm{mSv}$ ) of average total radiation dose received by the world's population is caused by natural and man-made radiation sources respectively (UNSCEAR 2006). The radiosensitivity of human organs and tissues which, depending on the type of irradiations (external and internal), varies considerably among individuals (HPA 2004). The harmful biological effects of irradiation which can lead to death, result generally from the exposure to high and/or low doses of radiation over a short and/or extended period of time respectively (Valentin 1994).

Among the most important contributors to external and internal exposure from natural radiation sources, we mainly distinguish gamma-ray radiations emitted by primordial natural radionuclides $\left({ }^{40} \mathrm{~K},{ }^{238} \mathrm{U}\right.$ and $\left.{ }^{232} \mathrm{Th}\right)$ and the radon isotopes (radon and thoron) and their decay products. Of this, the gamma ray radiations and inhalation of radon constitute respectively the second $(0.47 \mathrm{mSv}, 20 \%)$ and the first $(1.15 \mathrm{mSv}, 48 \%)$ largest natural sources of exposure (UNSCEAR 2008; 2019). Due to the fact that people spend most of their time (60\% up to $80 \%$ ) indoors (Saïdou et al. 2015; IAEA 2014; UNSCEAR 2000), exposure to natural radiation in the indoor environment could thus seriously affect population health and even become a public health problem in the world. The main sources of indoor exposure are related to geographical and geological features of soils on which homes are constructed, types of construction as well as materials used for buildings in each locality (Cosma et al. 2013; Sundal 2003).

Commonly known as the Africa in miniature, Cameroon is a sub-Saharan central Africa developing country endowed with a great mining potential. From 1937 to date, mining exploration activities which were carried out on only $40 \%$ on the national territory, revealed important mineral resources. Especially, uranium and thorium (North and South region), gold, cobalt, diamond (East and West region), bauxite, copper, rutile, iron, and rare-earth metals...etc (MINMIDT 2013). In recent years, the exploration, exploitation and processing of these world class mineral resources are promoted and encouraged by the State for the country's economic and social development objectives through the granting of numerous exploration (166), exploitation (05) and quarry exploitation (70) permits (MINMIDT 2013). Although, useful for the socio-economic development, all these human activities could have damaging consequences on the environment such as the pollution by radioactive materials.

About fifteen years ago, substantial studies have been carried out on population exposure to natural radiations in some regions in Cameroon. Ngachin et al. (2007), Ndontchueng et al. (2013), Gheumbou et al. (2017) and Ndjana et al. (2018) have respectively carried out the radioactivity measurements and radiation dose assessment of cement, sand, and soil used as building materials of some localities of Cameroon. Results obtained pointed out that these building materials do not present significant radiological risks to population and could be safely used. Passive integrated radon-thoron discriminative detectors (RADUET) and thoron progeny monitors were also deployed in some dwellings of uranium bearing region of Poli (Northern Cameroon), uranium and thorium bearing region of Lolodorf (Southern Cameroun), Douala city (Littoral Cameroon) and Betare-Oya gold mining areas (Eastern Cameroon) respectively by Saïdou et al. (2014; 2015), Bineng et al. (2020), Takoukam et al. (2019) and Ndjana et al (2019). These preliminary studies have enabled the simultaneous measurements of 
inhalation. More recently, RADTRAK detectors were used by Saïdou et al. (2020) to measure indoor radon in the bauxite-bearing areas in the southern Adamawa Region, Cameroon. The obtained results showed that $51 \%$ of dwellings have radon concentrations above the reference level of $100 \mathrm{~Bq} \mathrm{~m}^{-3}$ recommended by the World Health Organization (WHO).

\subsection{Motivation and contributions}

The present survey was conducted in some localities of Centre Region, Cameroon. Especially in Yaounde city, Okola, Obala, Monatélé and Mbalmayo towns. This region, which is home to the country's political and administrative capital (Yaounde), is the second most populated region in Cameroon (3,098,044 inhabitants; 17.7\%) after the Far North region $(3,111,792$ inhabitants; 17.8\%) (BUCREP 2010). The second most populated city in Cameroon, Yaounde alone represents $58.7 \%$ of the total population of the region. This strong demographic pressure, which has repercussions in the small towns (Okola, Obala, Monatélé and Mbalmayo) neighboring Yaounde, is accompanied by a very large exploitation of sand and gravel quarries used as building materials to face the high demand for housing.

The objective of the current study is to provide an answer to the almost inexistent radiological data resulting from certain building materials used in the Centre region on the one hand and to measure the concentration of radon in dwellings using RADTRAK detectors as well as assess radiological risks related to exposure to radon on the other hand. This work will contribute for the first time to estimate the EEDE and IEDE received by an individual occupying a dwelling throughout his life (life expectancy: 60 years) in the study areas. This will be made possible by taking into account the composition and the thickness variability of the structural elements (bare walls, plastered walls and floor) of the dwellings in the implementation of the RESRAD-BUILD code. Finally, in associating simulation calculations and measured data, the contribution of the dwelling type to the measured indoor radon concentration will be evaluated. The contribution of inhalation dose due to indoor radon to the total dose from RESRAD-BUILD code will also be assessed for the first time in such scientific studies.

\section{MATERIALS AND METHODS}

\subsection{Survey area}

The Centre Region of Cameroon is located between latitudes $3^{\circ}$ and $5^{\circ} \mathrm{N}$ and longitudes $11^{\circ}$ and $13^{\circ} \mathrm{E}$ (Fig. 1). This region covers an area of $68953 \mathrm{~km}^{2}$ with a total population projection for 2015 of over 4 million inhabitants (BUCREP 2010). This part of the country is under influence of a hot and humid equatorial climate of classic Guinean type with two rainy seasons (mid-March-mid-June and mid-August-mid November) interspersed with two dry seasons (mid-November-mid-March and mid-June-mid-August). The annual rainfall varies between 1500 and $1700 \mathrm{~mm}$ per year, while the average temperature is about $24^{\circ} \mathrm{C}$ (Kuitcha et al. 2012; Biram-Ngon et al. 2020).

Three main types of soils are found in this area: ferralitic, fersialitic and hydromorphic soils characteristic of riversides and wetlands. The parent material consists essentially of rock types in the Yaounde series. Situated in the panafrican fold belt, these rock types in the Yaounde series include chlorite-rich schists, garnet- and/or kyanite-bearing micaschists and garnet- and kyanite-bearing high-grade gneisses, thought to be derived from pelites and greywackes either in a continental margin or in a passive margin environment (Nzenti et al. 1988; Ngnotué et al. 2000). They are locally intruded by metamorphosed calc-alkaline dioritic plutons. 


\subsection{Radioactivity in some building materials}

114

115

116

117

118

119

120

121

122

123

124

125

126

127

128

129

130

131

132

133

134

135

136

137

138

139

140

141

142

143

144

145

146

147

\subsubsection{Primordial radionuclides in building materials}

Different kind of materials, especially, sixteen (16) crushed gneiss sand samples, four (04) alluvial (coarse and fine) sand samples, six (06) soil bricks samples and seven (07) portland cements samples used in building constructions were collected from different quarries and markets of Yaounde city and vicinity (Centre-region of Cameroon). These samples were oven-dried at $70^{\circ} \mathrm{C}$ for 2 days to ensure complete removal of moisture and some of them were crushed, homogenized and sieved with à $2 \mathrm{~mm}$ pore sieve. After a four weeks period (radioactive secular equilibrium between ${ }^{226} \mathrm{Ra} /{ }^{224} \mathrm{Ra}$ and ${ }^{222} \mathrm{Rn} /{ }^{220} \mathrm{Rn}$ ), the activity concentrations of ${ }^{226} \mathrm{Ra}$, ${ }^{232} \mathrm{Th}$ and ${ }^{40} \mathrm{~K}$ in the sealed samples were determined.

Gamma spectrometry technique with a Canberra $\mathrm{NaI}(\mathrm{Tl})$ detector was used to measure the activity concentrations of ${ }^{226} \mathrm{Ra},{ }^{232} \mathrm{Th}$ and ${ }^{40} \mathrm{~K}$. Precisely, model 802 scintillation NaI (Tl) detector with a crystal size of $7.6 \mathrm{~cm} \times 7.6 \mathrm{~cm}$ and a resolution of $7.5 \%$ at $667 \mathrm{keV}$, housed in a thick lead shield $(5 \mathrm{~cm})$ to minimize the contribution of surrounding radiations. The counting time was preset to $100,000 \mathrm{~s}$. The multi- $\gamma$-ray standard point sources of ${ }^{60} \mathrm{Co}(1173.2$ and $1332.5 \mathrm{keV}),{ }^{137} \mathrm{Cs}(661.9 \mathrm{keV}),{ }^{22} \mathrm{Na}(511$ and $1274.5 \mathrm{keV})$ and ${ }^{152} \mathrm{Eu}(1407.5,1112$, 964.079 and $778.9 \mathrm{keV}$ ) were used for energy calibration. The detector efficiency calibration was made possible, with standard sources of ${ }^{40} \mathrm{~K}(1460.8 \mathrm{keV}),{ }^{137} \mathrm{Cs}(661.6 \mathrm{keV}),{ }^{208} \mathrm{Tl}(2614.4 \mathrm{keV})$ and ${ }^{228} \mathrm{Ac}(940.1 \mathrm{keV})$ contained in a $500 \mathrm{~mL}$ Marinelli Beaker-resin volume. The spectral treatment was carried out using GENIE 2000 software. ${ }^{226} \mathrm{Ra}$ activity concentrations were estimated from the $609.3 \mathrm{keV}(44.8 \%)$ and the $1120 \mathrm{keV}(15.1 \%) \mathrm{y}$-peaks of ${ }^{214} \mathrm{Bi}$. Activity concentrations of ${ }^{232} \mathrm{Th}$ were obtained from the $911.6 \mathrm{keV}(26.6 \%) \mathrm{\gamma}$-peak of ${ }^{228} \mathrm{Ac}$ and those of ${ }^{40} \mathrm{~K}$ were determined from the $1460.8 \mathrm{keV}(10.67 \%) \mathrm{\gamma}$-peak of ${ }^{40} \mathrm{~K}$ itself. The minimum detectable activities of NaI (Tl) detector system for ${ }^{40} \mathrm{~K},{ }^{226} \mathrm{Ra}$ and ${ }^{232} \mathrm{Th}$ are $1.10,0.74$ and $0.43 \mathrm{~Bq} \mathrm{~kg}^{-1}$ respectively for a counting time of 100, 000s (Ndjana et al. 2018). Equations (1) and (2) below were used to calculate activity concentrations (Bq kg${ }^{1}$ ) of radionuclides and their corresponding combined uncertainties (IAEA 1989).

$$
A=\frac{S}{\varepsilon(E)_{\gamma} \cdot P \cdot M \cdot T}
$$

$$
\mu_{A}=A \sqrt{\left(\frac{\mu_{S}}{S}\right)^{2}+\left(\frac{\mu_{P}}{P}\right)^{2}+\left(\frac{\mu_{M}}{M}\right)^{2}+\left(\frac{\mu_{\varepsilon}}{\varepsilon}\right)^{2}}
$$

where $S$ is the net area under photo peak at energy $E(k e V), \varepsilon(E)_{\gamma}$ is the efficiency of detector at particular $\gamma$-ray energy $E, P$ is the $\gamma$-ray emission probability at energy $E, M$ is the sample weight $(\mathrm{kg}), T$ is the counting time (seconds) and $\mu$ is the standard deviation.

\subsubsection{External and internal dose assessment using RESRAD-BUILD Computer Code.}

The RESRAD-BUILD computer code was designed to estimate radiation doses incurred by an individual who works or lives in a building contaminated with radioactive material. This freely downloadable software was developed by Argonne National Laboratory (USA) and is available at https://web.evs.anl.gov/resrad/RESRAD_

Family/. In additional to the external and internal exposure pathway (direct external exposure from the source and indoor radon progeny products inhalation), the code allows analysis of many other external and internal irradiation pathways. In the RESRAD-BUILD code, the EEDE and IEDE due to direct exposure from external sources and 
inhalation of radon decay products respectively, resulting from occupancy of buildings contaminated by radioactive materials for a given exposure duration are expressed as follows (Yu et al. 2003):

$$
E E D E\left(m S v y^{-1}\right)=(E D / 365) \times F_{i n} \times G \times D C F \times \overline{A_{n}}
$$

$$
I E D E=K \times D C F \times W L M
$$

where $E E D E, \mathrm{ED}, F_{i n}, G, D C F, \overline{A_{n}}, I E D E, K$ and $W L M$ are the external effective dose equivalent, exposure duration (day), fraction of time spent indoors, geometrical factor for the infinite area, dose conversion factor $\left(\left(\mathrm{mSvy}^{-1}\right)\left(\mathrm{Bq} \mathrm{g}^{-1}\right)^{-1}\right)$, mean volume source concentration of the $n$ radionuclide (Bq g$\left.{ }^{-1}\right)$, internal effective dose equivalent, extrapolation doses factor from uranium mines to homes and the radon progeny concentration respectively.

Two room models of dimensions $4 \times 5 \times 2.8 \mathrm{~m}$ were considered for the evaluation of the total doses from the walls and floors of dwellings constructed with the sampled building materials and the effect of their thickness on this dose. For the first room model, the walls are made of bare bricks whereas for the second model, the walls are plastered with a layer of cement mortar. For both models, the floors are made typical of concrete. The EEDE and IEDE received by dwellers were evaluated for $0,1,10,20,30,40,50,60$ years of exposure.

The RESRAD-BUILD input parameters used for dose estimation are presented in Fig. 2. Additionally, the porosity, ${ }^{222} \mathrm{Rn}$ diffusivity and density of the building materials were assumed to be $0.1,2 \times 10^{-5} \mathrm{~m}^{2} \mathrm{~s}^{-1}$ and $2400 \mathrm{~kg} \mathrm{~m}^{-3}$, respectively.

\subsection{Indoor radon concentration and related radiological effects}

\subsubsection{Indoor radon concentration from building materials}

Although the main source of radon in the indoor environment is the basement of houses, building materials specially construction types also contribute, significantly in some cases, to increase indoor radon concentration. Thus, knowledge of the contribution of construction types to radon concentration level could be essential for the control, limitation and reduction of indoor radiations. In the steady conditions, the air quality model implemented in the RESRAD-BUILD code makes it possible to estimate the indoor radon concentration $\left(C_{R n B M}\right)$ knowing the concentration of its precursor, namely radium-226 $\left(C_{R a}\right)$, as illustrated in the below equation:

where $C_{R a}$ and $\varepsilon$ are the activity concentration of radium-226 in the building materials $\left(\mathrm{Bq} \mathrm{kg}{ }^{-1}\right)$ and radon emanation fraction, respectively. $\lambda$ and $\lambda \mathrm{v}$ are the radon decay constant $\left(\mathrm{h}^{-1}\right)$ and air exchange rate $\left(\mathrm{h}^{-1}\right)$ respectively. $\rho$ and $r$ are the density $\left(\mathrm{kg} \mathrm{m}^{-3}\right)$ and half thickness layer (m) of the structural elements (wall and floor) of room respectively, $A$ and $V$ are the room area $\left(\mathrm{m}^{2}\right)$ and the inner volume of the dwelling $\left(\mathrm{m}^{-3}\right)$.

\subsubsection{Indoor radon concentration measurements}

Indoor radon concentration was measured using RADTRAK ${ }^{2}$, a passive device based on Solid State Nuclear Track Detector (SSNTD) in a closed configuration as shown in Fig. 3. These dosimeters were provided by the International Atomic Energy Agency (IAEA) in the framework of the Technical Cooperation (TC) Project 
CMR9009 titled "Establishing a national radon plan for controlling public exposure due to radon indoors" managed by the IAEA and the Government of Cameroon. Radtrak ${ }^{2}$ dosimeter consists of one chamber, in which is mounted a transparent plastic film made of CR-39 polycarbonate (CR-39 detector) (RADONOVA 2019). This accumulation chamber has a small opening (filter) on its lower surface, through which the radon contained in the air infiltrates, diffuses and attains equilibrium with its daughters. During its decay, trapped radon emits alpha particles which hits and leave latent tracks on the CR-39 detector (RADTRAK 2021). For a measurement period of 3 months, the lower detection limit is $15 \mathrm{~Bq} \mathrm{~m}^{-3}$.

A total of 140 dwellings were selected for this survey. Most of dwellings in the study areas (Yaoundé

194 city, Monatélé, Obala, Okola and Mbalmayo towns) are simple type, without basement or storeys. In most cases, building materials consisted of earth, mud, sand from quarries and from river, land bricks and cement bricks. Indoor ventilation is mainly provided by the doors and the windows. Due to their limited number, each home received one RADTRAK detector. The detectors were preferably installed in the bedroom (considered as space where resident spent a lot of their time), at a height of 1.5-2.0 $\mathrm{m}$ from the floor and as far as possible from windows and doors in order to avoid air currents. The exposure period of detectors in dwellings was chosen between the months of October and December 2019 because it is an inter-season period, where there are rainy and dry seasons. After the measurement period, the detectors were collected and sent back to RADONOVA Laboratories in Uppsala, Sweden for tracks evaluation.

Generally, chemical and/or electrochemical treatment of the CR-39 detectors is carried out in order to make alpha particles latent tracks more visible. The tracks were then counted using the tracks counting system (digital optical microscope) followed by determination of the radon exposure. According to part 4 of ISO 11665 standard (2012), activity concentration $\left(\mathrm{Bq} \mathrm{m}^{-3}\right)$ was calculated from the superficial track density using the following equation:

$$
C_{R n}\left(B q . m^{-3}\right)=\frac{D_{e}-D_{f}}{C F . T_{e}} \text { with } \quad D=\frac{N}{S} F
$$

where $\boldsymbol{D} \boldsymbol{e}$ is the track density of exposed detector (tracks $/ \mathrm{m}^{2}$ ), $\boldsymbol{D} \boldsymbol{f}$ is the track density of background detectors $\left(\right.$ tracks $\left./ \mathrm{m}^{2}\right), \boldsymbol{C F}$ is the calibration factor $\left(\mathrm{Bq} \mathrm{m} \mathrm{m}^{-3} \mathrm{~h} /\right.$ tracks $\left./ \mathrm{m}^{2}\right), \boldsymbol{N}$ is the number of etched tracks counted by the counting system (digital optical microscope), $\boldsymbol{S}$ is the detector surface and $\boldsymbol{F}$ is the correction factor of the counting system (microscope) given by the manufacturer determined from the counting of etched tracks with other methods. The radon concentrations uncertainties (standard deviation) were calculated at the $68 \%$ confidence level according to the ISO 11665 part 4.

\subsubsection{Effective inhalation dose due to measured indoor radon concentration}

Exposure to radon and its progeny can induce a variety of cytogenetic effects such as chromosome mutations, chromosome aberrations, etc. Those effects can be biologically damaging and result in an increased risk of carcinogenesis (Valentin 1994). It is thus essential and vital to know radiation dose attributable to indoor radon and its progeny received by population. Two methods were used in this study to assess effective dose. Radon exposure which can be converted into effective dose was calculated in terms of WLM year ${ }^{-1}$ (Raghavendra et al 2014) by using the following equation:

$$
W L M \text { year }^{-1}=C_{R n} \times F \times T \times(170 \times 3700)^{-1}
$$

Additionally, the UNSCEAR model of annual effective dose, which takes into account the dissolution of radon gas in blood, using the following equation (UNSCEAR 2000): 
For the two above expressions, $\boldsymbol{C}_{\boldsymbol{R} \boldsymbol{n}}$ is radon concentration in $\mathrm{Bq} \mathrm{m}^{-3}, \boldsymbol{F}$ is the equilibrium factor for radon (0.4), $\boldsymbol{T}$ is indoor exposure time per year $(0.7 \times 8760 h), \boldsymbol{\varepsilon}_{\boldsymbol{r}}=\mathbf{0 . 1 7} \mathrm{nSv}\left(\mathrm{Bq} \mathrm{h} \mathrm{m}^{-3}\right)^{-1}$ is the dose coefficient for radon gas dissolved in blood and $\varepsilon_{\boldsymbol{d}}$ is the inhalation dose conversion factor $\left(9 \mathrm{nSv}(\mathrm{Bq} \mathrm{h} \mathrm{m})^{-3}\right)$ for radon. The ICRP conversion factor for radon $\left(16.8 \mathrm{nSv}\left(\mathrm{Bq} \mathrm{h} \mathrm{m}^{-3}\right)^{-1}\right)$ was also used to determine the inhalation dose using ICRP dosimetric approach (Tokonami et al. 2020).

\subsubsection{Radiological risk indicators due to indoor radon exposure}

It is well known that after tobacco, indoor radon exposure is the second main risk factor for lung cancer (WHO 2009). The lung cancer risk from the measured indoor radon levels can be estimated from several radon risk indicators.

\section{Excess Lifetime Cancer Risk (ELCR)}

In radiation protection, the ELCR designates the probability / risk for an individual exposed to a certain dose of radiation to develop cancer during a specific period time. From the local Life Span (LS; 60y), the fatal Risk Factor $(\boldsymbol{R F})$ recommended by ICRP $\left(0.055 \mathrm{~Sv}^{-1}\right)$ and the annual equivalent dose rate $\boldsymbol{H}_{\text {lung }}$, the ELCR was calculated using the following formula (Sherafat et al. 2019):

$$
E L C R=H_{\text {lung }} \times L S \times R F
$$

\section{Excess lung Cancer Risk (ECR)}

Excess lung Cancer Risk (ECR) is defined as the number of additional deaths per Million of Persons per Year (MPY) due to lung cancer as a result of exposure to radon and its progeny. The ECR was estimated by using the following equation (Khatibeh et al. 1997):

$$
E C R=E F \times O F \times \text { Risk Factor } \times W L M
$$

where $\boldsymbol{E} \boldsymbol{F}$ is the Equilibrium Factor between radon and its progeny, $\boldsymbol{O F}$ is the Occupancy Factor which correspond to the fraction of time that people spend indoors. For this study, a default value of $\boldsymbol{E F}, \boldsymbol{O F}(0.4,0.8)$ given by UNSCEAR 2000 were used. Risk Factor is the lifetime risk of lung cancer mortality due to lifetime exposure to radon and its progeny. In other words, it is the number of lung cancer deaths Per Million Persons (PMP) per Working Level Month (WLM). According to the calculation models used and the epidemiological data for exposed mine workers, various scientific committees and agencies (UNSCEAR, ICRP and US-EPA) have assessed the risk coefficients which are given in Table 1.

\section{Excess Relative Risk (ERR)}

The ERR of radon induced lung cancer is an epidemiological indicator which accounts to the increase risk incurred by a population exposed to radon inhalation to develop a lung cancer compared to that of a nonexposed population (WHO 2009). Among the numerous models available in literature, the U.S. Environmental Protection Agency (U.S-EPA) radon risk model (EPA 2003), was used in this study to estimate the ERR resulting from indoor radon exposure. This chosen model is a scaled version exposure-age-concentration model presented by the National Research Council, Biological Effects of Ionizing Radiations (BEIR VI) committee for use in residential exposures (NRC 1999). In summary, the mathematical form of the EPA/BEIRVI model for the ERR at a given age is described as:

$$
E R R(a)=\beta\left(w_{5-14}+0.78 w_{15-25}+0.51 w_{+25}\right) \times \varphi_{a g e}(a)
$$


where $\beta(=0.0634)$ represents the excess relative risk per radon exposure, $w_{i}$ is radon exposure received in time window i before current age. The 0.78 and 0.51 coefficients represent the weights of the $15-24$ and $\geq 25$ timesince-exposure windows. The coefficient $\varphi_{\text {age }}$ refers to attained age.

266

267

\section{RESULTS AND DISCUSSION}

\subsection{Natural Radioactivity levels and long-term radiological dose analysis}

\subsubsection{Natural radioactivity levels in building materials}

Table 2 presents the statistical parameters of the activity concentrations of natural radionuclides in the investigated building materials in the study areas. The lowest mean values of the activity concentrations of ${ }^{226} \mathrm{Ra}$, ${ }^{232} \mathrm{Th}$ and ${ }^{40} \mathrm{~K}$ are $13 \pm 2,17 \pm 2$ and $66 \pm 13 \mathrm{~Bq} \mathrm{~kg}^{-1}$ respectively, measured in alluvial fine sand samples. The brick samples revealed the highest arithmetical mean value for ${ }^{226} \mathrm{Ra}$ and ${ }^{232} \mathrm{Th}$ which are $40 \pm 6 \mathrm{~Bq} \mathrm{~kg}^{-1}$ and $83 \pm 10 \mathrm{~Bq}$ $\mathrm{kg}^{-1}$ respectively. The maximum mean concentration of ${ }^{40} \mathrm{~K}$ obtained, was in crushed gneiss sand with a value of $443 \pm 94 \mathrm{~Bq} \mathrm{~kg}^{-1}$.

The world average values of ${ }^{226} \mathrm{Ra},{ }^{232} \mathrm{Th}$ and ${ }^{40} \mathrm{~K}$ activity concentrations in the building materials are 50 , 50 and $500 \mathrm{~Bq} \mathrm{~kg}^{-1}$, respectively (UNSCEAR 2008). It appears that average values of ${ }^{232} \mathrm{Th}$ for the crushed gneiss sand and brick samples are higher than the corresponding world average activity concentrations. Therefore, the mean activity concentrations of the overall sampled building materials (Table 2) are found to be lower than the world average values.

\subsubsection{Long term radiological dose analysis using RESRAD-BUILD}

The radiological dose evaluation of the structural elements (wall and floor) of the houses made from various compositions of the sampled building materials as shown in Table 3 was carried out using activity concentrations of natural radionuclides obtained in this study. The RESRAD-BUILD input parameters for ${ }^{226} \mathrm{Ra}$, ${ }^{232} \mathrm{Th}$, and ${ }^{40} \mathrm{~K}$ activity concentrations used in the simulation are presented in Table 3.

Figs. 4, 5 and 6 show the EEDE and IEDE obtained according to the variation of walls and concrete floor thickness of dwellings for long-term exposure. For the room made mainly of bare brick walls and whose the thickness ranges from 10 to $20 \mathrm{~cm}$, the EEDE and IEDE values range from 0.32 to $0.46 \mathrm{mSv} \mathrm{y}^{-1}$ and 1.40 to 2.04 $\mathrm{mSv}^{-1}$ respectively (Fig 4). For plastered walls, the cement mortar layer covering these walls with a thickness ranging from 1 to $5 \mathrm{~cm}$, presents an EEDE and IEDE which varies from 0.02 to $0.12 \mathrm{mSv} \mathrm{y}^{-1}$ and 0.08 to $0.43 \mathrm{mSv}$ $\mathrm{y}^{-1}$ respectively (Fig. 5). The changes in concrete thickness for soil room recovering from 10 to $60 \mathrm{~cm}$ gives an EEDE and IEDE ranging from 0.10 to $0.14 \mathrm{mSv} \mathrm{y}^{-1}$ and 0.20 to $0.40 \mathrm{mSv}^{-1}$ respectively (Fig. 6). The corresponding standard deviations for the above types of housing structural elements were approximately $9 \%, 37 \%$ and $15 \%$ respectively.

These results (Fig. 4, 5 and 6) which show that the equivalent doses increase over the exposure period (up to 60 years) are well below the recommended limit of $1.5 \mathrm{mSv} \mathrm{y}^{-1}$ for building materials (NEA-OECD 1979) except for bare brick walls homes. It can also be observed that the effective dose equivalents and room structural elements (walls and floor) thickness show an almost linear correlation. It can be seen from Fig. 6, that from a floor concrete thickness of $30 \mathrm{~cm}$, external dose decreases. This behavior of decreasing external dose when the thickness of the floor concrete is greater than $30 \mathrm{~cm}$ has also been reported by Risica et al. (2001), Majid et al. (2013) and 
Kocsis et al. (2021). These authors assumed that for thicknesses of concrete greater than $30 \mathrm{~cm}$, self-absorption occurred.

\subsection{Indoor radon concentration and annual effective inhalation dose}

\subsubsection{Building materials indoor radon concentration}

The standard rooms as well as the input parameters (radium concentration, etc.) used to evaluate the indoor radon concentration from building materials are same as those described and implemented by the RESRADBUILD code in the section above. The indoor radon concentration for the rooms made in bare brick walls, in plastered walls by a cement mortar layer and concrete covering the room floor varies from $8 \pm 1$ to $12 \pm 2 \mathrm{~Bq} \mathrm{~m}^{-3}$, $4 \pm 1$ to $8 \pm 1 \mathrm{~Bq} \mathrm{~m}^{-3}$ and $5 \pm 1$ to $10 \pm 1 \mathrm{~Bq} \mathrm{~m}^{-3}$ respectively. The corresponding mean values are $10 \pm 1,6 \pm 1$ and $7 \pm 2$ $\mathrm{Bq} \mathrm{m}^{-3}$ respectively. These results, which are similar to those obtained by Kumar et al. (2014), reveal that the indoor radon concentration from building materials in the considered standard rooms is far below the WHO action level $\left(100 \mathrm{~Bq} \mathrm{~m}^{-3}\right)$.

\subsubsection{Measured indoor radon concentration levels}

The results of indoor radon concentrations measured in the study areas are summarized in Table 4. The arithmetic (geometric) average concentration of indoor radon in Yaounde, Okola, Obala, Monatele and Mbalmayo buildings were $59 \pm 13(53 \pm 13), 37 \pm 11(34 \pm 11), 30 \pm 11(27 \pm 11), 25 \pm 10(24 \pm 10), 37 \pm 11(33 \pm 11) \mathrm{Bq}$ $\mathrm{m}^{-3}$ respectively. For the study areas, activity concentrations of radon ranges from $15 \pm 10$ to $140 \pm 20 \mathrm{~Bq} \mathrm{~m}^{-3}$ with arithmetic and geometric means of $42 \pm 12$ and $36 \pm 12 \mathrm{~Bq} \mathrm{~m}^{-3}$ respectively. For the 140 dwellings chosen for this study, only three dwellings in Yaounde city have concentrations $\left(116,136\right.$ and $\left.140 \mathrm{~Bq} \mathrm{~m}^{-3}\right)$ above the World Health Organization reference level $\left(100 \mathrm{~Bq} \mathrm{~m}^{-3}\right)$. The lifestyle of the occupants and accumulation of dust in these three houses could be the sources of this relatively high level of radon. Furthermore, the indoor radon concentrations recorded in the study areas are well below the reference level (300 $\left.\mathrm{Bq} \mathrm{m}^{-3}\right)$ given by the ICRP (2010).

The histogram showing the frequency distribution of radon activity concentrations in the investigated area is presented in Fig. 7. Normality and log-normality distributions of indoor radon activity concentration were evaluated using Kolmogorov-Smirnov and Lilliefors tests. The probability values ( $p$-values) obtained from these tests were about $1 \%$ and $1.3 \times 10^{-4} \%$ for normality, $52 \%$ and $10 \%$ for log-normality tests respectively. Thus, the frequency distribution of indoor radon activity concentrations follows a log-normal distribution according to null hypothesis for normality assumption.

The average indoor radon concentration values for each of the locality were compared with each other, as shown in Fig. 8. It can be observed that for all these localities, radon concentrations do not present a major difference and are slightly below the world average value of $40 \mathrm{~Bq} \mathrm{~m}^{-3}$ (UNSCEAR 2000) except that of Yaounde city (about $59 \pm 13 \mathrm{~Bq} \mathrm{~m}^{-3}$ ).

\subsubsection{Contribution of construction types in the indoor radon concentration levels}

One observes that, in associating simulation calculations and measured data, construction types, especially those with bare brick walls, cement mortar plastered walls and concrete covering the floor, present an average contribution of $22 \%, 13 \%$ and $16 \%$ respectively, in the average indoor radon concentration of the whole study area. These results are in agreement with those of UNSCEAR (1993) which states that $21 \%$ of indoor radon concentration comes from building materials.

\subsubsection{Annual exposure rate and effective inhalation dose due to measured indoor radon}



are presented in Table 5. For the 140 houses, radon exposure rate and effective inhalation dose received by the occupants varied from 0.06 to $0.55 \mathrm{WLM} \mathrm{y}^{-1}$ with a mean value of $0.16 \pm 0.09 \mathrm{WLM} \mathrm{y}^{-1}$ and 0.35 to $3.24 \mathrm{mSv}^{-}$

${ }^{1}$ with an average of $0.96 \pm 0.55 \mathrm{mSv}^{-1}$ respectively. The standard deviation has been considered as uncertainty in the average calculations. This average value of inhalation dose is lower than the world average of $1.15 \mathrm{mSv}^{-}$ ${ }^{1}$ (UNSCEAR 2000). Among the five investigated localities, Yaounde city has the highest inhalation dose (1.35 \pm $0.31 \mathrm{mSv} \mathrm{y}^{-1}$ ). When considering the ICRP 137 (ICRP 2017) conversion factor $16.8 \mathrm{nSv}\left(\mathrm{Bq} \mathrm{h} \mathrm{m}^{-3}\right)^{-1}$ for radon progeny (Fig. 9), the evaluated inhalation dose increases to $77 \%$ (1.75 \pm 1.01$)$ compared to that obtained using the UNSCEAR conversion factor, but remains well below the lower limit of the recommended action level of 3-10 $\mathrm{mSv} \mathrm{y}^{-1}$.

\subsubsection{Comparison of the RESRAD-BUILD dose model and inhalation dose from the indoor radon measured.}

Standard dwellings resulting from the two room models considered above are made of brick walls, which are covered with a layer of cement mortar and finally a floor covered with a layer of concrete. The total dose simulated by the RESRAD-BUILD code, received by an individual occupying this housing model, varies from 2.12 to $3.50 \mathrm{mSv} \mathrm{y}^{-1}$ with a mean value of $1.49 \mathrm{mSv} \mathrm{y}^{-1}$ and a standard deviation of $0.88 \mathrm{mSv}^{-1}$ for an exposure period up to 60 years. The average contribution of measured indoor radon $\left(0.96 \pm 0.55 \mathrm{mSv} \mathrm{y}^{-1}\right)$ corresponds to about $65 \%$ of this total simulated dose. This result is similar to that of the NCRP report 160 (2009) which showed that $68 \%$ of the total dose stems from indoor radon. Thus, indoor radon appears to be by far the largest contributor to the natural radiation dose.

\subsection{Radiological Risk indicators related to indoor radon exposure}

To better appreciate the radiological risks due to indoor radon exposure, three risk indicators were assessed and summarized in Table 6. These include, excess lifetime cancer risk (ELCR), excess lung cancer risk (ECR) and excess relative risk (ERR) for age group of 35 and 55.

The estimated values of the ELCR across the study areas ranged from $(4.53 \pm 1.47$ to $10.62 \pm 4.59) \times 10^{-3}$ with a mean value of $(7.57 \pm 4.38) \times 10^{-3}$. This obtained average value, is approximately 1.7 times lower the action level value $\left(13 \times 10^{-3}\right)$ given by EPA (2003) for the public. This result shows that, even for prolonged exposure to radon indoors, the risk of developing fatal lung cancer by residents is relatively low in the study areas.

As displayed in Table 6, the calculated ECR for all selected houses are 5.19-18.04, 6.77-20.30 and 11.28 which are well below the world average values of 25-87, 32-97 and 54 reported by the US-EPA (1986), UNSCEAR (1988) and ICRP (1987) respectively. This result shows that, at most $0.002 \%$ of people could die per year from lung cancer as result of radon exposure in the study areas.

For inhabitants who are 35 years old, for the study areas, the ERR (Table 6) ranges from $0.14 \pm 0.04$ to $0.33 \pm 0.15$ with an average value of $0.23 \pm 0.13$. While for those who are 55 , it varies from $0.11 \pm 0.03$ to $0.27 \pm 0.12$ with a mean of $0.19 \pm 0.11$. Thus, the risk of a radon-induced lung cancer death is increased by 23 and $19 \%$ for residents aged 35 and 55 years respectively in the study areas. These values are relatively lower compared to those observed in the literature. 


\section{CONCLUSION}

In this study, natural radioactivity measurements of some building materials and the related long-term external and internal doses analysis using RESRAD-BUILD computer code followed by indoor radon study and assessment of some associated radiological risk indicators were investigated. Activity concentrations of ${ }^{226} \mathrm{Ra}$, ${ }^{232} \mathrm{Th}$ and ${ }^{40} \mathrm{~K}$ for the overall sampled building materials (37) were found to vary between $10 \pm 2-52 \pm 7 \mathrm{~Bq} \mathrm{~kg}^{-1}$, $10 \pm 1-95 \pm 10 \mathrm{~Bq} \mathrm{~kg}{ }^{-1}$ and $31 \pm 1-673 \pm 20 \mathrm{~Bq} \mathrm{~kg}^{-1}$ with the arithmetic mean values of $28 \pm 4 \mathrm{~Bq} \mathrm{~kg}^{-1}, 46 \pm 6 \mathrm{~Bq} \mathrm{~kg}^{-1}$ and $274 \pm 58 \mathrm{~Bq} \mathrm{~kg}^{-1}$ respectively. The EEDE and IEDE obtained according of the thickness variations of bare brick walls, cement mortar plaster layer and concrete floor of the dwelling for an exposure up to 60 years ranges from 0.32-0.46 mSv $\mathrm{y}^{-1}$ and 1.40-2.04 $\mathrm{mSv} \mathrm{y}^{-1}, 0.02-0.12 \mathrm{mSv} \mathrm{y}^{-1}$ and $0.08-0.43 \mathrm{mSv} \mathrm{y}^{-1}$ and $0.10-0.14 \mathrm{mSv} \mathrm{y}^{-1}$ and $0.20-0.40 \mathrm{mSv} \mathrm{y}^{-1}$ respectively. Estimated indoor radon concentration from structural elements of standard rooms varies from $8 \pm 1-12 \pm 2,4 \pm 1-8 \pm 1$ and $5 \pm 1-10 \pm 1 \mathrm{~Bq} \mathrm{~m}^{-3}$ for those with bare brick walls, cement mortar plaster layer and concrete floor respectively. The corresponding mean values are $10 \pm 1,6 \pm 1$ and $7 \pm 2 \mathrm{~Bq} \mathrm{~m}-3$ respectively, which together with the measured data, these dwelling structural elements contribute to $22 \%, 13 \%$ and $16 \%$ of the indoor radon concentration respectively. Using RADTRAK dosimeters, indoor radon concentrations measured in the 140 houses were found to vary between $15 \pm 10$ and $140 \pm 20 \mathrm{~Bq} \mathrm{~m}^{-3}$ with an arithmetic mean of $42 \pm 12 \mathrm{~Bq} \mathrm{~m}^{-}$ ${ }^{3}$. Only 3 dwellings (2.14\% of the selected houses) had concentrations above the World Health Organization reference level $\left(100 \mathrm{~Bq} \mathrm{~m}^{-3}\right)$ and none above the IAEA recommended value of $300 \mathrm{~Bq} \mathrm{~m}^{-3}$. The annual inhalation dose ranged from 0.35 to $3.24 \mathrm{mSv} \mathrm{y}^{-1}$ with an average of $0.96 \pm 0.55 \mathrm{mSv} \mathrm{y}^{-1}$, which is lower than the world average value of $1.15 \mathrm{mSv} \mathrm{y}^{-1}$. In associating simulation calculations and measured data, the contribution of measured inhalation dose is about $65 \%$ of total simulated dose. This confirms that radon is by far the largest contributor to the natural radiation dose. The overall analysis of radiological risk indicators related to radon in homes such as ELCR, ECR and ERR estimated in this study indicates a relatively low level of risk compared to those of permissible limits. This present work, which contributed for the first time not only to predict the longterm doses received by an individual occupying a dwelling but also to assess the contribution of the dwelling types to indoor radon levels, shows that the study areas do not present a significant radiological risk to the public. However, it would be desirable to educate the members of the public on certain habits and routine lifestyles that could increase radiological risks and harm their health. Thus, this work could be used as baseline for radiological monitoring of the area.

\section{ACKNOWLEDGEMENTS}

The authors are grateful to the Abdus Salam ICTP for its support through the OEA-AF-12 project at CEPAMOQ

This work was also supported by IAEA within the framework of the Technical Cooperation (TC) Project CMR9009 titled "Establishing a national radon plan for controlling public exposure due to radon indoors" in terms of equipment and trainings. The Government of Cameroon through the Public Investment Budget 2019 of the Ministry of Scientific Research and Innovation is acknowledged.

\section{Declarations}

\section{Ethics approval and consent to participate}

"Not applicable" 


\section{Consent for publication}

"Not applicable"

\section{Availability of data and materials}

The datasets used and/or analyzed during the current study are available from the corresponding author on reasonable request.

\section{Competing interests}

The authors declare that they have no competing interests

\section{Funding}

- This work was supported by IAEA within the framework of the Technical Cooperation (TC) Project CMR9009 titled "Establishing a national radon plan for controlling public exposure due to radon indoors" in terms of equipment and trainings.

- And by the Government of Cameroon through the public investment 2019 budget of the Ministry of Scientific Research and Innovation.

\section{Authors' contributions}

- JENNII participated in field works (building materials sampling and Radtrak dosimeter deployment), data analysis, writing;

- $\quad$ AM participated in field works (building materials sampling and Radtrak dosimeter deployment), data analysis;

- Saïdou participated in conception, funding and reviewing;

- $\quad$ OG participated in the funding and reviewing;

- $\quad$ CS participated in the reviewing;

- $\quad$ MGKN participated in the conception and reviewing.

All authors read and approved the final manuscript.

\section{$\underline{\text { References }}$}

Bineng GS, Tokonami S, Hosoda M, Siaka YFT, Issa H, Suzuki T, Kudo H, Bouba O, Saïdou (2020) The Importance of Direct Progeny Measurements for Correct Estimation of Effective Dose Due to Radon and Thoron. Front. Public Heal 8, 17. doi:10.3389/ fpubh.2020. 00017.

Biram-Ngon EB, Foto MS, Ndjama J, Mbohou NZ, Mboye BR, Dzavi J, Oumar MO, Tarkang C, Nyame MDO, Mbondo BS, Ngalamou C (2020) Water Quality Assessment in a Less Anthropogenic Forest Stream in the Centre Region of Cameroon. Haya Saudi J Life Sci 5(01), 1-8.

BUCREP (2010) Rapport de presentation des resultats definitif.. Bureau Central des Recensements et des Etudes de Population. Yaoundé.

Cosma C, Cucos -Dinu A, Papp B, Begy R, Sainz C (2013) Soil and building material as main sources of indoor radon in Baita-Stei radon prone area (Romania). Journal of Environmental Radioactivity 116, 174-179.

EPA (2003) Assessment of risks from radon in homes. Environmental Protection Agency, Office of Radiation and Indoor Air. Washington, DC.

Guembou SCJ, Ndontchueng MM, Chene G, Nguelem MJE, Motapon O, Kayo SA, Strivay D (2017) Assessment of natural radioactivity and associated radiation hazards in sand building material used in Douala Littoral Region of Cameroon, using gamma spectrometry. Environ Earth Sci 76,164. DOI 10.1007/s12665-0176474-3

HPA (2013) Human Radiosensitivity, report of the independent advisory group of ionizing radiation. Health Protection Agency, 2013.

IAEA (1989) Technical Reports Series No. 229: Measurement of radionuclides in food and the environment, a guidebook. International Atomic Energy Agency. Vienna. 
IAEA (2014) SSG-32 Protection of the Public against Exposure Indoors due to Radon and Other Natural Sources of Radiation. International Atomic Energy Agency. Vienna, 2014.

ICRP (1987) Lung cancer risk from indoor exposure to radon daughters. International Commission on Radiological Protection Publication 50. Pergamon Press, Oxford.

ICRP (1994) Protection against Radon-222 at Home and at Work. International Commission on Radiological Protection Publication 65. Pergamon Press, Oxford.

ICRP (2010) Lung cancer risk from radon and progeny and statement on radon. International Commission on Radiological Protection Publication 115.

ICRP (2017) Occupational Intakes of Radionuclides: Part 3. Annals of the ICRP. International Commission on Radiological Protection; New York, NY, USA.

ISO 11665-4 (2012) Measurement of radioactivity in the environment - Air: radon-222 - Part 4: Integrated measurement method for determining average activity con-centration using passive sampling and delayed analysis. International Organization for Standardization. Geneva, Switzerland.

Khatibeh AJAH, Ahmed N, Matiullah (1997) Indoor radon levels in some regions of Jordan and assessment of the associated excess lung cancer risk. The Nucleus 34, 11- 15.

Kuitcha D, Fouépé TAL, Ndjama J, Takem EG, Tita AM, Kamgang KBV, Ekodeck GE (2012) Chemical and isotopic signal of precipitation in yaounde-cameroon. Arch. Appl. Sci. Res 4 (6):2591-2597.

Kocsis E, Tóth-Bodrogi E, Peka A, Adelikhah M, Kovács T (2021) Radiological impact assessment of diferent building material additives. Journal of Radioanalytical and Nuclear Chemistry. https://doi.org/10.1007/s10967-021-07897-4

Kumar A, Chauhan RP, Manish J, Sahoo BK (2014) Modeling of indoor radon concentration from radon exhalation rates of building materials and validation through measurements. Journal of Environmental Radioactivity 127 (2014) $50-55$.

Majid AA, Ismail AF, Yasir MS, Yahaya R, Bahari I (2013) Radiological dose assessment of naturally occurring radioactive materials in concrete building materials. J Radioanal Nucl Chem 297(2): 277-284.

McLean AR, Adlen EK, Cardis E, Elliott A, Goodhead DT, Harms-Ringdah M, Hendry JH, Jeggo PA, Mackay DJC, Muirhead CR, Shepherd J, Shore RE, Thomas GA, Wakeford R, Godfray HCJ (2017) A restatement of the natural science evidence base concerning the health effects of low-level ionizing radiation. Proc. $R$. Soc 2017. B284:20171070. http://dx.doi.org/10.1098 /rspb. 2017.1070

MINMIDT (2013) Mining Potential, https://minmidt-gov.net/en/target-sectors/mining-sector/ miningpotential.html (accessed on 22 April 2021).

NCRP report 160 (2009) Ionizing Radiation Exposure of the Population of the United States. Bethesda, MD: National Council on Radiation Protection and Measurements.

Ndjana NIIJE, Simplice Feutseu TS, Bineng GS, Manga A, Tchuente SYF, Saïdou (2018) Natural Radioactivity Measurements in Soil, External Dose and Radiological Hazard Assessment in the Uranium and Thorium Bearing Region of Lolodorf, Cameroon. Radioisotopes 67, 435-446.

Ndjana NIIJE, Ngoa EL, Saïdou, Masahiro H, Bongue D, Takahito S, Kudo H, Kwato NMG, Tokonami S (2019) Simultaneous indoor radon, thoron and thoron progeny measurements in betare-oya gold mining areas, eastern Cameroon. Radiat. Prot. Dosim. doi:10.1093/rpd/ncz026.

Ndontchueng MM, Nguelem MEJ, Simo A, Njinga RL, Beyala JF, Kryeziu D (2013) Preliminary investigation of naturally occurring radionuclide in some six representative cement types commonly used in Cameroon as building material. Radiation Protection and Environment 36, 2. DOI: 10.4103/0972-0464.128871

NEA-OECD (1979) Exposure to radiation from natural radioactivity in building materials. Report by NAE group expert. OECD, Paris.

Ngachin M, Garavaglia M, Giovani C, Kwato NMG, Nourreddine A (2007) Assessment of natural radioactivity and associated radiation hazards in some Cameroonian building materials. Radiation Measurements 42, 61-67.

Ngnotué T, Nzenti JP, Barbey P, Tchoua FM (2000) The Ntue-Betamba high-grade gneisses: a northward extension of the Pan-African-Yaounde gneisses in Cameroon. Journal of African Earth Sciences 31, 369 381 . 
NRC (1999) Committee on the Health Risks of Exposure to Radon (BEIR VI): Health Effects of Exposure to Radon. Committee on the Biological Effects of Ionizing Radiations, National Research Council. National Academy Press. Washington, DC.

Nzenti JP, Barbey P, Macaudiere J, Soba D (1988) Origin and evolution of the late Precambrian high-grade Yaounde gneisses (Cameroon). Precambrian Research 38, 91-109.

RADONOVA (2019) $\operatorname{Radtrak}^{2}{ }^{\circledR}$ - the world's leading detector for long-term radon measurement. https://radonova.com/radtrak2_world_leading_detector/ (accessed on 30 April 2021).

RADTRAK (2021) Alpha track detector for long term measurements. https://www.sfu.ca/content /sfu/radon/Howyoucanhelp/_jcr_content/main_content/download_0/file.res/Alpha\%20Track\%20Detect or.pdf (accessed on 30 April 2021).

Raghavendra T, Ramakrishna SUB, Vijayalakshmi T, Himabindu V, Arunachalam J (2014) Assessment of radon concentration and external gamma radiation level in the environs of the proposed uranium mine at Peddagattu and Seripally regions, Andhra Pradesh, India. Journal of radiation research and applied sciences 269-273. http://dx.doi.org/10.1016/j.jrras.2014.03.007.

Risica S, Bolzan C, Nuccetelli C (2001) Radioactivity in building materials: room model analy-sis and experimental methods. Sci Total Environ 272(1-3):119-126. http://www.ncbi.nlm.nih.gov/ pubmed/11379899.

Saïdou, Abdourahimi, Tchuente SYF, Bouba O (2014) Indoor radon measurements in the uranium regions of Poli and Lolodorf, Cameroon. J Environ Radioact, 136, 36-40. doi: 10.1016/j.jenvrad.2014.05.001.

Saïdou, Tokonami S, Janik M, Samuel BG, Abdourahimi, Ndjana NIIJE (2015) Radon thoron discriminative measurements in the high natural radiation areas of Southwestern Cameroon. J Environ Radioact 150, 242-246.

Saïdou, Abiama EP, Tokonami S (2015) Comparison study of natural radiation exposure to the public in three uranium and oil regions of Cameroon. Radioprotection 50, 265-271.

Saïdou, Modibo OB, Ndjana NIIJE, German O, Kountchou NM, Abba HY (2020) Indoor Radon Measurements Using Radon Track Detectors and Electret Ionization Chambers in the Bauxite-Bearing Areas of Southern Adamawa, Cameroon. Int. J. Environ. Res. Public Health 17, 67-76. doi:10.3390/ijerph17186776.

Sherafat S, Mansour SN, Mosaferi M, Aminisani N, Yousefi Z, Maleki S (2019) First Indoor Radon Mapping and Assessment Excess Lifetime Cancer Risk in Iran. Methods X 6, 2205-2216. https://doi.org/10.1016/j.mex.2019.09.028.

Sundal AV (2003) Geologic influence on indoor radon concentrations and gamma radiation levels in Norwegian dwellings, Doctor scientiarum thesis Department of Earth Science, University of Bergen.

Takoukam SSD, Tokonami S, Hosoda M, Suzuki T, Kudo H, Bouba O, Saïdou (2019) Simultaneous measurements of indoor radon and thoron and inhalation dose assessment in Douala City, Cameroon. Isot. Environ. Heal. Stud 55, 499-51. doi:10.1080/10256016.2019.1649258.

Tokonami S (2020) Characteristics of Thoron (220Rn) and Its Progeny in the Indoor Environment. Int. J. Environ. Res. Public Health 17, 8769. doi:10.3390/ijerph17238769

UNSCEAR (1988) Report to the General Assembly. United Nations Scientific Committee on the Effects of Atomic Radiation Sources and Effects of Ionizing Radiation. New York.

UNSCEAR (1993) Report to the General Assembly. United Nations Scientific Committee on the Effects of Atomic Radiation Sources and Effects of Ionizing Radiation. New York.

UNSCEAR (2000) Sources and Effects of Ionizing Radiation. United Nations Scientific Committee on the Effect of Atomic Radiation. Exposure from Natural Radiation Sources, Annex B. United Nation Publication, New York.

UNSCEAR (2006) Sources, effects and ionizing radiation: report to the general assembly with scientific annexes. United Nations Scientific Committee on the Effect of Atomic Radiation, United Nation New York.

UNSCEAR (2008) Effects of ionizing radiation: Report to the General Assembly with scientific annexes. United Nations Scientific Committee on the Effects of Atomic Radiation. United Nations Publications, New York.

UNSCEAR (2019) Sources, Effects and risks of Ionizing Radiation. United Nations Scientific Committee on the Effect of Atomic Radiation. Lung Cancer from Exposure to Radon, Annex B. United Nation Publication, New York. 


\begin{tabular}{lcl}
\hline $\begin{array}{c}\text { International committees/ } \\
\text { agencies }\end{array}$ & $\begin{array}{c}\text { Cancer deaths per million person } \\
\text { (PMP) per WLM }\end{array}$ & References \\
\hline US-EPA (1986) & $115-400$ & (US-EPA 1986) \\
ICRP (1987) & 250 & (ICRP 1987) \\
UNSCEAR (1988, 1993) & $150-450$ & (UNSCEAR 1988) \\
\hline
\end{tabular}

US-EPA (1986) Radon reduction methods: a homeowner's guide. United State of Environmental Protection Agency. Washington, DC.

Valentin J (1994) Radiation: levels and doses in everyday life. Radioprotection 29 (3, Suppl.): 45-58.

WHO (2009) WHO handbook on indoor radon: a public health perspective. World Health Organization. Geneva. Yu C. et al (2003) “User's Manual for RESRAD-BUILD Version 3”

\section{$\underline{\text { Tables }}$}

Table 1 Risk factors for some scientific committees and agencies
571

Table 2 Statistical parameters of natural radioactivity in common building materials used in some localities of the Region of Centre, Cameroon.

\begin{tabular}{|c|c|c|c|c|}
\hline \multirow[b]{2}{*}{ Material } & \multirow[b]{2}{*}{ statistical parameters } & \multicolumn{3}{|c|}{ Activity concentrations $\left(\mathrm{Bq} \mathrm{kg}^{-1}\right)$} \\
\hline & & ${ }^{226} \mathrm{Ra}$ & ${ }^{232} \mathrm{Th}$ & ${ }^{40} \mathrm{~K}$ \\
\hline \multirow[t]{4}{*}{ Crushed gneiss sand } & $\operatorname{Min}-\operatorname{Max}^{\mathrm{a}}$ & $24-48$ & $45-86$ & $383-673$ \\
\hline & $\mathrm{AM} \pm \mathrm{CU}^{\mathrm{a}}$ & $32 \pm 4$ & $54 \pm 7$ & $443 \pm 94$ \\
\hline & $\mathrm{GM} \pm \mathrm{CU}^{\mathrm{a}}$ & $31 \pm 4$ & $54 \pm 7$ & $438 \pm 51$ \\
\hline & $\mathrm{N}^{\mathrm{a}}$ & 16 & 16 & 16 \\
\hline \multirow[t]{4}{*}{ Alluvial fine sand } & $\operatorname{Min}-\operatorname{Max}^{\mathrm{a}}$ & $10-18$ & $11-25$ & $35-94$ \\
\hline & $\mathrm{AM} \pm \mathrm{CU}^{\mathrm{a}}$ & $13 \pm 2$ & $17 \pm 2$ & $66 \pm 14$ \\
\hline & $\mathrm{GM} \pm \mathrm{CU}^{\mathrm{a}}$ & $13 \pm 2$ & $16 \pm 2$ & $61 \pm 13$ \\
\hline & $\mathrm{N}^{\mathrm{a}}$ & 4 & 4 & 4 \\
\hline \multirow[t]{4}{*}{ Alluvial coarse sand } & $\operatorname{Min}-\operatorname{Max}^{\mathrm{a}}$ & $15-24$ & $21-41$ & $31-425$ \\
\hline & $\mathrm{AM} \pm \mathrm{CU}^{\mathrm{a}}$ & $18 \pm 3$ & $35 \pm 4$ & $228 \pm 48$ \\
\hline & $\mathrm{GM} \pm \mathrm{CU}^{\mathrm{a}}$ & $18 \pm 2$ & $34 \pm 4$ & $119 \pm 25$ \\
\hline & $\mathrm{N}^{\mathrm{a}}$ & 4 & 4 & 4 \\
\hline \multirow[t]{4}{*}{ Bricks } & $\operatorname{Min}-\operatorname{Max}^{\mathrm{a}}$ & $32-52$ & $58-95$ & $49-204$ \\
\hline & $\mathrm{AM} \pm \mathrm{CU}^{\mathrm{a}}$ & $40 \pm 6$ & $83 \pm 10$ & $111 \pm 23$ \\
\hline & $\mathrm{GM} \pm \mathrm{CU}^{\mathrm{a}}$ & $39 \pm 5$ & $81 \pm 10$ & $94 \pm 20$ \\
\hline & $\mathrm{N}^{\mathrm{a}}$ & 6 & 6 & 6 \\
\hline \multirow[t]{4}{*}{ Porland cement } & $\operatorname{Min}-\operatorname{Max}^{\mathrm{a}}$ & $10-35$ & $10-25$ & $75-233$ \\
\hline & $\mathrm{AM} \pm \mathrm{CU}^{\mathrm{a}}$ & $26 \pm 4$ & $18 \pm 3$ & $173 \pm 37$ \\
\hline & $\mathrm{GM} \pm \mathrm{CU}^{\mathrm{a}}$ & $24 \pm 4$ & $17 \pm 2$ & $162 \pm 35$ \\
\hline & $\mathrm{N}^{\mathrm{a}}$ & 7 & 7 & 7 \\
\hline \multirow[t]{4}{*}{$\begin{array}{l}\text { The Overall sampled } \\
\text { building materials }\end{array}$} & $\operatorname{Min}-\operatorname{Max}^{\mathrm{a}}$ & $10-52$ & $10-95$ & $31-673$ \\
\hline & $\mathrm{AM} \pm \mathrm{CU}^{\mathrm{a}}$ & $28 \pm 4$ & $46 \pm 6$ & $274 \pm 58$ \\
\hline & $\mathrm{GM} \pm \mathrm{CU}^{\mathrm{a}}$ & $26 \pm 4$ & $39 \pm 4$ & $198 \pm 42$ \\
\hline & $\mathrm{N}^{\mathrm{a}}$ & 37 & 37 & 37 \\
\hline
\end{tabular}


a Min: minimum value; Max: maximum value; AM: arithmetic mean; CU: Combined Uncertainty (coverage factor=1); GM: geometric mean; N: number of samples.

Table 3 The input parameters of activity concentrations and combined uncertainties (68\% confidence level) used in RESRAD-BUILD computer code

\begin{tabular}{|c|c|c|c|c|c|}
\hline \multirow{2}{*}{$\begin{array}{l}\text { Structural elements } \\
\text { of the houses }\end{array}$} & \multirow[b]{2}{*}{ Materials } & \multirow{2}{*}{$\begin{array}{l}\text { Composition of the structural } \\
\text { elements of the houses }\end{array}$} & \multicolumn{3}{|c|}{ Specific Activity $\left(\mathrm{Bq} \mathrm{kg}^{-1}\right)$} \\
\hline & & & ${ }^{226} \mathrm{Ra}$ & ${ }^{232} \mathrm{Th}$ & ${ }^{40} \mathrm{~K}$ \\
\hline Bare Walls (BW) & Brick & $90 \%$ Brick & $36 \pm 5$ & $75 \pm 9$ & $100 \pm 21$ \\
\hline \multirow[t]{5}{*}{ Plastering Walls (PW) } & \multirow[t]{5}{*}{ Cement mortar } & $25 \%$ Portland Ciment & $7 \pm 1$ & $5 \pm 1$ & $43 \pm 9$ \\
\hline & & $35 \%$ alluvial fine sand & $5 \pm 1$ & $6 \pm 1$ & $23 \pm 5$ \\
\hline & & $20 \%$ alluvial coarse sand & $4 \pm 1$ & $7 \pm 1$ & $46 \pm 10$ \\
\hline & & $20 \%$ Crushed gneiss sand & $7 \pm 1$ & $11 \pm 2$ & $89 \pm 19$ \\
\hline & & Total (Mortar) & $23 \pm 4$ & $29 \pm 5$ & $201 \pm 43$ \\
\hline \multirow[t]{4}{*}{ Floor $(\mathrm{Fl})$} & \multirow[t]{4}{*}{ Concrete } & $10 \%$ Portland Ciment & $3 \pm 1$ & $2 \pm 1$ & $18 \pm 4$ \\
\hline & & $30 \%$ alluvial fine sand & $4 \pm 1$ & $5 \pm 1$ & $20 \pm 4$ \\
\hline & & $60 \%$ gravel (crushed gneiss sand) & $19 \pm 3$ & $32 \pm 5$ & $266 \pm 56$ \\
\hline & & Total (Concrete) & $26 \pm 5$ & $39 \pm 7$ & $304 \pm 64$ \\
\hline
\end{tabular}

579

Table 4 Activity concentrations of indoor radon

\begin{tabular}{|c|c|c|c|c|c|c|}
\hline \multirow{2}{*}{$\begin{array}{l}\text { Statistical } \\
\text { parameters }\end{array}$} & \multirow[b]{2}{*}{ Yaounde } & \multicolumn{5}{|c|}{ Activity concentration $\left(\mathrm{Bq} \mathrm{m}^{-3}\right)$} \\
\hline & & Okola & Obala & Monatélé & Mbalmayo & $\begin{array}{c}\text { Whole study } \\
\text { area }\end{array}$ \\
\hline Range & $19-140$ & $21-93$ & $15-64$ & $15-45$ & $15-90$ & $15-140$ \\
\hline $\mathrm{AM} \pm \mathrm{SD}^{\mathrm{a}}$ & $59 \pm 13$ & $37 \pm 11$ & $30 \pm 11$ & $25 \pm 10$ & $37 \pm 11$ & $42 \pm 12$ \\
\hline $\mathrm{GM}(\mathrm{SD})^{\mathrm{a}}$ & $53 \pm 13$ & $34 \pm 11$ & $27 \pm 11$ & $24 \pm 10$ & $33 \pm 11$ & $36 \pm 12$ \\
\hline Median & 52 & 30 & 26 & 24 & 26 & 34 \\
\hline$N^{\mathrm{a}}$ & 51 & 22 & 23 & 21 & 23 & 140 \\
\hline
\end{tabular}

Table 5. The annual WLM, effective doses and corresponding standard deviations for 140 dwellings of Centre Region, Cameroon

\begin{tabular}{|c|c|c|c|c|c|c|c|}
\hline \multirow{3}{*}{ Study area } & \multirow{3}{*}{$\begin{array}{l}\text { Number } \\
\text { of houses }\end{array}$} & & & \multicolumn{4}{|c|}{ Annual inhalation effective dose, $\mathrm{mSv} \mathrm{y}^{-1} 585$} \\
\hline & & \multicolumn{2}{|c|}{ WLM/year } & \multicolumn{2}{|c|}{ UNSCEAR, 2000} & ICRP 137 & 586 \\
\hline & & Range & $\begin{array}{l}\text { Arithmetic } \\
\text { mean } \pm \text { SD }\end{array}$ & Range & $\begin{array}{l}\text { Arithmetic } \\
\text { mean } \pm \mathrm{SD}\end{array}$ & Range & $\begin{array}{l}\text { Arithmetic } \\
\text { mean }+\frac{ \pm}{58} \text { D }\end{array}$ \\
\hline Yaounde & 51 & $0.07-0.55$ & $0.23 \pm 0.10$ & $0.44-3.24$ & $1.35 \pm 0.63$ & $0.81-5.91$ & $2.45 \pm 1.15$ \\
\hline Okola & 22 & $0.08-0.36$ & $0.15 \pm 0.06$ & $0.49-2.15$ & $0.85 \pm 0.39$ & $0.89-3.93$ & $1.55 \pm 5088$ \\
\hline Obala & 23 & $0.05-0.25$ & $0.12 \pm 0.04$ & $0.35-1.48$ & $0.68 \pm 0.28$ & $0.64-2.70$ & $1.23 \pm 0.52$ \\
\hline Monatele & 21 & $0.04-0.18$ & $0.09 \pm 0.03$ & $0.35-1.04$ & $0.57 \pm 0.19$ & $0.43-1.90$ & $1.04 \pm 5089$ \\
\hline Mbalmayo & 23 & $0.06-0.35$ & $0.14 \pm 0.06$ & $0.35-2.08$ & $0.85 \pm 0.41$ & $0.64-3.80$ & $1.55 \pm 0.75$ \\
\hline $\begin{array}{l}\text { Whole } \\
\text { study area }\end{array}$ & 140 & $0.06-0.55$ & $0.16 \pm 0.09$ & $0.35-3.24$ & $0.96 \pm 0.55$ & $0.64-5.91$ & $\begin{array}{r}590 \\
1.75 \pm 1.01\end{array}$ \\
\hline
\end{tabular}


Table 6 The calculated radiological risk indicators and corresponding standard deviations from radon exposure in the whole study area

\begin{tabular}{|c|c|c|c|c|c|c|}
\hline \multirow[b]{2}{*}{ Study area } & \multirow[b]{2}{*}{$\operatorname{ELRC}\left(\mathrm{x} 10^{-3}\right)$} & \multicolumn{3}{|c|}{$\begin{array}{l}\text { Estimated excess lung cancer risk per } \\
\text { MPY using the recommended risk } \\
\text { factors (per WLM) of the following } \\
\text { international agencies }\end{array}$} & \multirow{2}{*}{$\begin{array}{c}\text { ERR for } 35 \\
\text { years }\end{array}$} & \multirow{2}{*}{$\begin{array}{l}\text { ERR for } 55 \\
\text { years }\end{array}$} \\
\hline & & US-EPA & UNSCEAR & ICRP & & \\
\hline Yaounde & $10.62 \pm 4.59$ & $7.27-25.31$ & $9.49-28.47$ & 15.82 & $0.33 \pm 0.15$ & $0.27 \pm 0.12$ \\
\hline Okola & $6.72 \pm 3.08$ & $4.61-16.03$ & $6.01-18.03$ & 10.02 & $0.21 \pm 0.09$ & $0.17 \pm 0.07$ \\
\hline Obala & $5.32 \pm 2.27$ & $3.64-12.67$ & $4.75-14.26$ & 7.92 & $0.17 \pm 0.07$ & $0.14 \pm 0.05$ \\
\hline Monatele & $4.53 \pm 1.47$ & $3.05-10.60$ & $3.97-11.92$ & 6.62 & $0.14 \pm 0.04$ & $0.11 \pm 0.03$ \\
\hline Mbalmayo & $6.71 \pm 3.28$ & $4.60-16.00$ & $6.00-17.00$ & 10.00 & $0.21 \pm 0.10$ & $0.17 \pm 0.08$ \\
\hline $\begin{array}{l}\text { Whole study } \\
\text { area }\end{array}$ & $7.57 \pm 4.38$ & $5.19-18.04$ & $6.77-20.30$ & 11.28 & $0.23 \pm 0.13$ & $0.19 \pm 0.11$ \\
\hline $\begin{array}{l}\text { Average } \\
\text { worlwide values }\end{array}$ & $\begin{array}{c}13 \\
\text { (EPA 2003) }\end{array}$ & $25-87$ & $32-97$ & 54 & I & I \\
\hline
\end{tabular}

594

595

596

597

598

599

600

601

602

603

604

605

606

607

608

609

610

\section{Figure captions}

Fig. 1 Survey area localization.

Fig. 2 RESRAD-BUILD interface with the input parameters used in the work.

Fig. 3 Schematic diagram and features of radtrak $^{2}$ in closed configuration with

1. Diffusion chamber $(\varnothing=58 \mathrm{~mm}) ; 2$. CR-39 polycarbonate film $(2.5 \mathrm{~mm} \times 2 \mathrm{~mm})$;

3. Bottom face of RADTRAK ${ }^{2}$; 4. Filter (air exchange) and 5. Support with ID number of device.

Fig. 4 Effective dose equivalents at different bare brick wall thickness. Straight and dash lines represent internal and external exposure respectively.

Fig. 5 Effective dose equivalents at different cement mortar plaster thickness. Straight and dash lines represent internal and external exposure respectively.

Fig. 6 Effective dose equivalents at different floor concrete thickness. Straight and dash lines represent internal and external exposure respectively.

Fig. 7 Distribution of indoor radon concentration in the whole study area.

Fig. 8 Variation of radon concentration for the five localities investigated.

Fig. 9 UNSCEAR and ICRP inhalation dose comparison. 
Figures

\section{Figure 1}

Survey area localization.

An RESRAD-BUILD : C:IRESRAD_Family $\backslash B U I L D \backslash 3.5 \backslash C$ rushed_gneiss_sand.bld

File View Modify Help

\begin{tabular}{|c|c|c|c|c|c|}
\hline 98 & 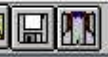 & 4 & 嘼 & 只 & DCF \\
\hline \multicolumn{6}{|l|}{ Case } \\
\hline \multicolumn{6}{|c|}{ Case } \\
\hline Title & \multicolumn{5}{|c|}{$\begin{array}{l}\text { Doses assessment of the building } \\
\text { materials of Centre region. Cameroon }\end{array}$} \\
\hline \multicolumn{6}{|c|}{ Dose/Risk Library } \\
\hline \multicolumn{4}{|c|}{ ICRP 72 (Adult) } & - & \\
\hline \multicolumn{6}{|c|}{ - Time Parameters } \\
\hline \multirow[t]{2}{*}{ 回 } & \multicolumn{3}{|c|}{$\begin{array}{l}\text { Exposure Duration [days] } \\
\text { Indoor fraction }\end{array}$} & \begin{tabular}{|l|}
25550 \\
0.7 \\
\end{tabular} & \\
\hline & \multicolumn{3}{|c|}{ Evaluation Times } & & \\
\hline
\end{tabular}

\section{Building Parameters}

\begin{tabular}{|l|l|l|}
\hline Number of Rooms & 1 \\
\hline & Deposition Velocity & \\
\hline & 0.01 & $\mathrm{~m} / \mathrm{s}$ \\
\hline
\end{tabular}

Resuspension Rate 0.0000005

Air Flow

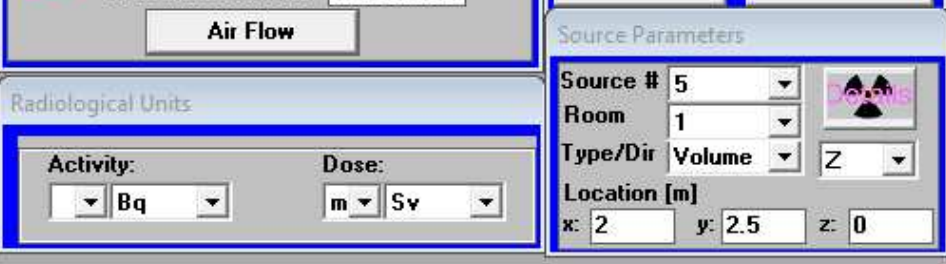

\begin{tabular}{|c|c|c|}
\hline Receptor \# & 1 & $\checkmark$ \\
\hline Room & 1 & 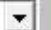 \\
\hline Time Fraction & 1 & \\
\hline Breathing Rate & 20 & $\mathrm{~m}^{3} \mathrm{~s}$ \\
\hline $\begin{array}{l}\text { Ingestion Rate } \\
\text { Location [m] }\end{array}$ & 0.0001 & \\
\hline$y: 2.5$ & $z: 1$ & \\
\hline
\end{tabular}

Shielding Parameters

\begin{tabular}{|c|c|c|}
\hline Thickness & 0 & $\mathrm{~cm}$ \\
\hline Density & 2.4 & g/ce \\
\hline Material & Concrete & $\nabla$ \\
\hline
\end{tabular}

View Table

Copy Shielding
Display

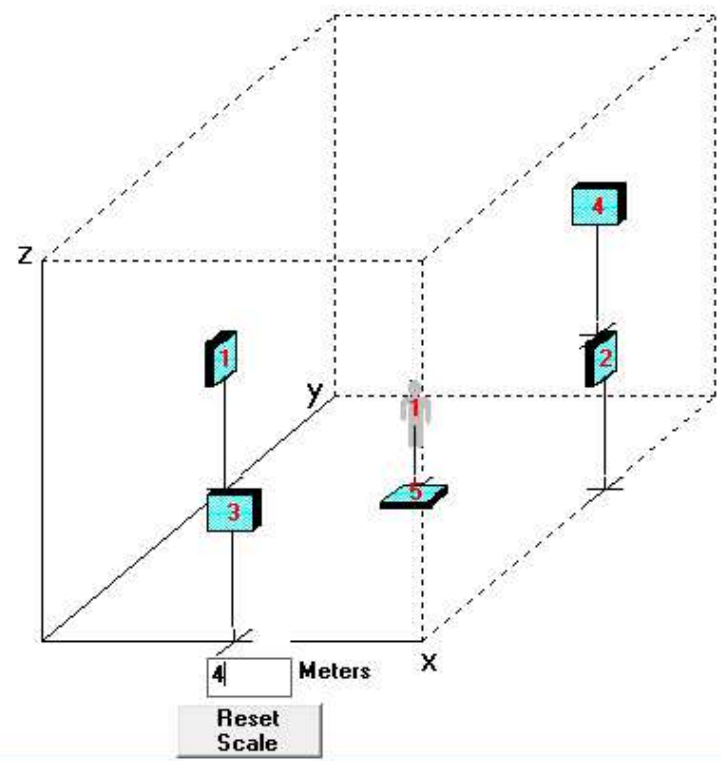

\section{Figure 2}

RESRAD-BUILD interface with the input parameters used in the work. 


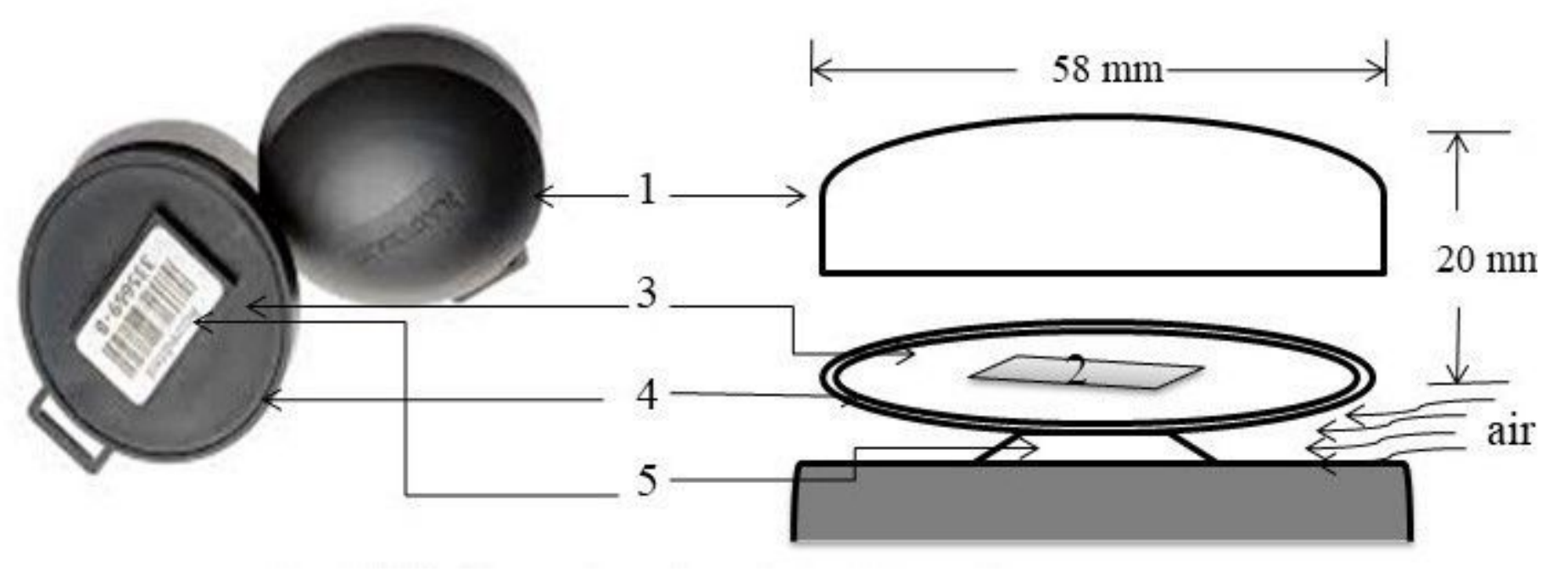

Figure 3

Schematic diagram and features of radtrak ${ }^{2}$ in closed configuration with

1. Diffusion chamber $(\varnothing=58 \mathrm{~mm}) ; 2$. CR-39 polycarbonate film $(2.5 \mathrm{~mm} \times 2 \mathrm{~mm})$;

3. Bottom face of RADTRAK ${ }^{2}$; 4 . Filter (air exchange) and 5. Support with ID number of device.

\section{Figure 4}

Effective dose equivalents at different bare brick wall thickness. Straight and dash lines represent internal and external exposure respectively.

\section{Figure 5}

Effective dose equivalents at different cement mortar plaster thickness. Straight and dash lines represent internal and external exposure respectively.

\section{Figure 6}

Effective dose equivalents at different floor concrete thickness. Straight and dash lines represent internal and external exposure respectively. 
Figure 7

Distribution of indoor radon concentration in the whole study area.

Figure 8

Variation of radon concentration for the five localities investigated.

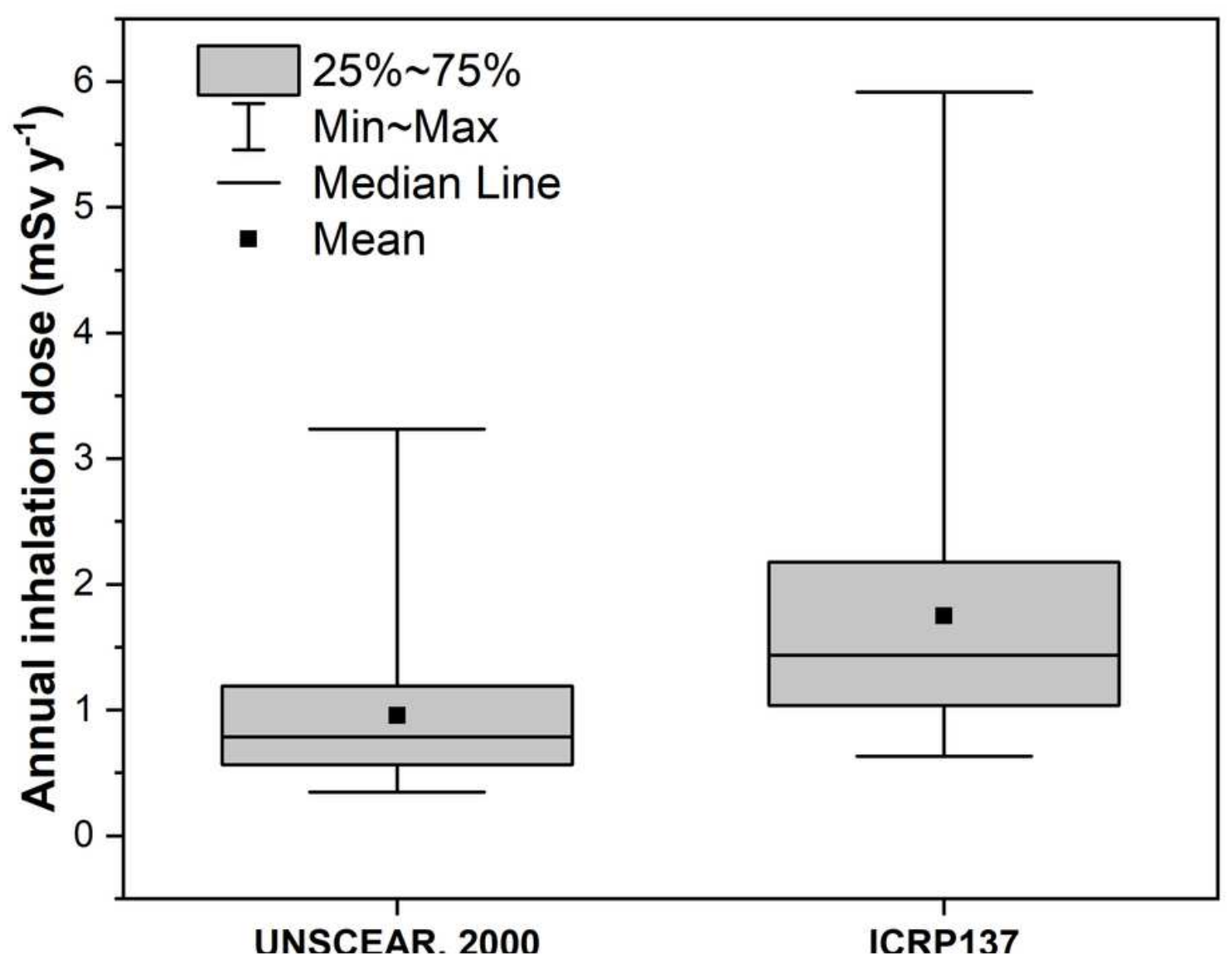

Figure 9

UNSCEAR and ICRP inhalation dose comparison. 